\title{
MODELLING ASPECTS OF LASER CLADDING OF BIOACTIVE GLASS COATINGS ON ULTRAFINE-GRAINED TITANIUM SUBSTRATES
}

\author{
SZYMON BAJDA*, MiCHAL KRZYZANOWSKI \\ AGH University of Science and Technology, al. Mickiewicza 30, 30-059 Krakow, Poland \\ *Corresponding author: sbajda@agh.edu.pl
}

\begin{abstract}
Titanium alloys, due to their exceptional mechanical properties and biocompatibility, are commonly used to produce medical implants nowadays. However, the presence of such elements as aluminium and vanadium can be harmful to human health. One of the possible solutions could be replacing the titanium alloys with ultrafine-grained commercially pure titanium (cpTi). The yield and also the ultimate strength of cpTi can exceed $1000 \mathrm{MPa}$. One of the most promising methods in manufacturing medical implants with improved biological fixation is laser cladding in which bioactive glass coatings are imposed on metallic substrates. The aim of this work is development of a 3D numerical model of the above mentioned additive manufacturing process. The obtained model is able to predict the stress-strain and temperature distributions during the processing. A sequentially coupled finite element (FE) model of laser cladding has been developed by applying element birth and death technique to calculate the transient temperature fields used in the stress analysis. The concentrated volumetric heat source from the laser beam moving along the metal surface has been represented by the Gaussian distribution in the radial and exponential decay in the depth direction. The developed FE based numerical model is capable to support the optimal design of such advanced multi-layered structural materials using the laser cladding technique.
\end{abstract}

Key words: Laser cladding, Ultrafine-grained materials, Finite element analysis, Bioactive glass.

\section{INTRODUCTION}

Biomaterial, according to American National Institute of Health, is defined as "any substance or combination of substances, other than drugs, synthetic or natural in origin, which can be used for any period of time, which augments or replaces partially or totally any tissue, organ or function of the body, in order to maintain or improve the quality of life of the individual" (Bergmann \& Stumpf, 2013; Kar, 2016).

The main feature obligatory for a biomaterial is its biocompatibility, i.e. the capability to interact with the human organism by not being toxic, injurious and without causing immune response. Additionally, biomaterials can be divided according to their reaction with the body tissue into "bioinert", "bioactive" and "bioresorbable" materials (Sola et al., 2011).
The introduction of bioinert materials into the body will not cause chemical or biological bond at the implant/tissue interface resulting in relative movements between them, which can initiate inflammatory reactions (Hench, 1991). Hence, their potential applications can only be successful when the prosthesis is implanted with a tight mechanical fit and loaded in compression. With this purpose in mind, some methods like cementation have been developed in order to create adhesion between a bio-inert material and the attached bone (Schlegel et al., 2014). Another approach is utilization of natural adhesive phenomena by morphological, mechanical interlock, and biological fixation, such as tissue ingrowth into porous implant (Cao \& Hench, 1996; Hench, 1998). However, there are still many problems relevant to adhesion in 
both cases, motivating the search for alternative fixation methods.

Bioactive materials attracted the world-wide attention at the beginning of the 1970s, when Professor Larry Hench discovered special glass, called Bioglass ${ }^{\circledR}$, capable of forming interfacial bonding with the attached bone (Hench \& Paschall, 1973). It has been proven by numerous studies both in vivo and in vitro that they create hydroxyapatite (HA) surface layer, very similar to the mineral component of bones, which allow them to form a biological bond with both hard and soft tissues instead of being rejected by the body (Hench \& Wilson, 1993). Such bonding mechanism has been called "bioactive fixation". Its main advantage is that a bioactive connection to bone may reach strength even greater than bone after 3-6 months (Hench, 1998).

Bioresorbable materials are characterized by the ability to gradually degrade in body environment and to be replaced by a newly formed host tissue (Madeo, 2015). Their degradation rate should match the natural tissue formation rate. Furthermore, bioresorbable implants should be able to provide proper mechanical support during the replacement process (Vallet-Regí, 2010).

Titanium alloys, which are bioinert materials, are most widely used to produce medical implants due to their exceptional mechanical properties, corrosion resistance and biocompatibility (Liu et al., 2004). However, they are two main problems with their application for orthopaedic implants: i) they contain alloying elements, such as aluminium and vanadium, which may be potentially toxic when released into human system (Elias et al., 2013), ii) their bonding to bone is not strong enough due to interfacial stability problems with the host tissues (Ramaswamy et al., 2009; Shi et al., 2007).

First issue may be resolved by replacing titanium alloys with commercially pure titanium (cpTi) having ultrafine-grained structure free of potentially toxic elements. The yield and also the ultimate strength (UTS) of cpTi can exceed $1000 \mathrm{MPa}$, which is even higher to those of titanium alloys (Elias et al., 2013; Stolyarov et al., 2003).

The bonding to bone of the titanium implant may be greatly enhanced by covering the titanium surface with some bioactive material able to form a biological bond with host tissue. One of the most important bioactive and bioresorbable materials are bioactive glasses and ceramics. Glasses (generally based on mixtures of $\mathrm{SiO} 2, \mathrm{CaO}, \mathrm{MgO}, \mathrm{Na} 2 \mathrm{O}, \mathrm{K} 2 \mathrm{O}$ and
P2O5), due to their high bioactivity, osteoconduction and osteostimulation, are commonly used as a bone filling materials, small bone implants and for dental applications (Miguez-Pacheco et al., 2015). Calcium phosphates, the most popular bioactive ceramics, are applied e.g. in orthopaedic and trauma surgery, periapical surgery and dentistry (Dorozhkin, 2016). Ceramics and glasses are excellent bioactive or bioresorbable materials, but cannot be used alone due to intrinsic brittleness and relatively poor mechanical properties limiting their clinical applications to nonload bearing implants. Hence, they can be imposed as a coatings on mechanically tough non-bioactive metallic substrates to improve fixation and osteointegration of the whole implant device (Comesaña et al., 2010; Pou et al., 2010). Furthermore, a bioactive glass/ceramic coating protects the substrate from corrosion and, as a consequence, protects host tissues from corrosion products that could cause some adverse reactions in human organism (Baino \& Verné, 2017; Verné, 2012).

One of the most promising techniques that has been successfully applied for deposition of the bioactive glass on titanium alloy substrate is laser cladding (Comesaña et al., 2010; Krzyzanowski et al., 2016). In laser cladding (figure 1), a laser beam is focused onto the metallic substrate in order to form a melt pool, and simultaneously bioactive glass (in powdered form) is delivered onto it by an inert gas. As the laser beam moves, rapid quenching of the molten pool takes place and as a result a bioactive glass coating is formed on the metallic substrate. Examples of using laser cladding technique for obtaining bioactive glass coatings are given in (Comesaña et al., 2010; Del Val et al., 2016; Kongsuwan et al., 2015).

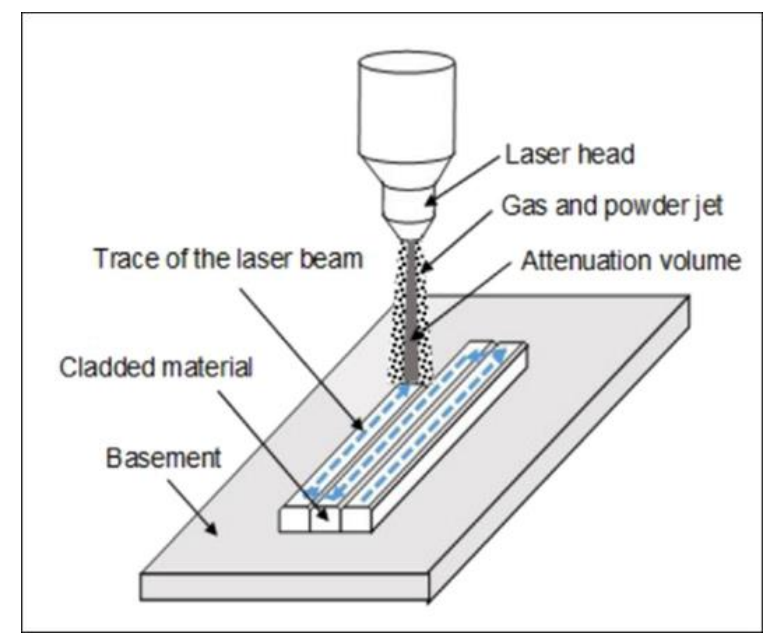

Fig. 1. Schematic representation of the laser cladding process (Krzyzanowski et al., 2016). 
The aim of this work is development of the 3D numerical model capable to simulate the laser cladding of bioactive glass coatings on ultrafine-grained metallic substrates. Model can predict the stressstrain and temperature distributions during the processing.

\section{NUMERICAL MODEL}

3D FE based model of the laser cladding of bioactive glass coatings on ultrafine-grained cpTi Grade 4 has been developed and applied for the analysis using Abaqus/Standard software (figure 2). A sequentially coupled approach has been used, which means that the results from the thermal analysis have been transferred to the followed stress analysis in order to perform the thermal stress calculations. The heat transfer resulting from the thermal load of the moving laser beam has been calculated in a fully transient heat transfer analysis. Next, the temperature results, as the loading with the objective to determine transient strains and stresses induced in the heat affected zone (HAZ), have been used in the structural analysis.

The model consists of two sets of 3D elements. The first set represents the ultrafine-grained cpTi substrate while the second one the 45S5 bioactive glass material accumulated on the base plate surface. In the experiential laser cladding process, the bioactive material is cladded gradually along with the laser beam movement as it is shown in figure 1 . In the numerical modelling, increase of the amount of cladded bioactive material has been taken into account using a timedependent activation of the finite elements (also known as the birth and death technique). Initially, the cladded layers have been meshed during the model configuration. Then, at the beginning of the numerical analysis, they have been deactivated. Next, the cladded chunks have been selectively activated depending on the cladding speed as has been shown in figure 2 .

The metallic substrate has been assumed $10 \mathrm{~mm}$ long, $10 \mathrm{~mm}$ wide and $2 \mathrm{~mm}$ thick, consisting of 3620 8 -node linear heat transfer brick elements. Three consecutive cladded layers of 45S5 bioactive glass have been considered in the numerical simulation. Each layer has been built from chunks, where each chunk is $1 \mathrm{~mm}$ long, $1 \mathrm{~mm}$ wide and $0.5 \mathrm{~mm}$ thick consisting of 48 elements of the same type as the metallic substrate. The nodes situated at the substrate corners (indicated by letter A, B and C in figure 2) have been constrained to prevent rigid body motion in the following way:

- node A has been fully constrained,

- node $\mathrm{B}$ has been constrained in directions $\mathrm{Y}$ and Z,

- node $\mathrm{C}$ has been constrained in directions $\mathrm{X}$ and $\mathrm{Y}$.

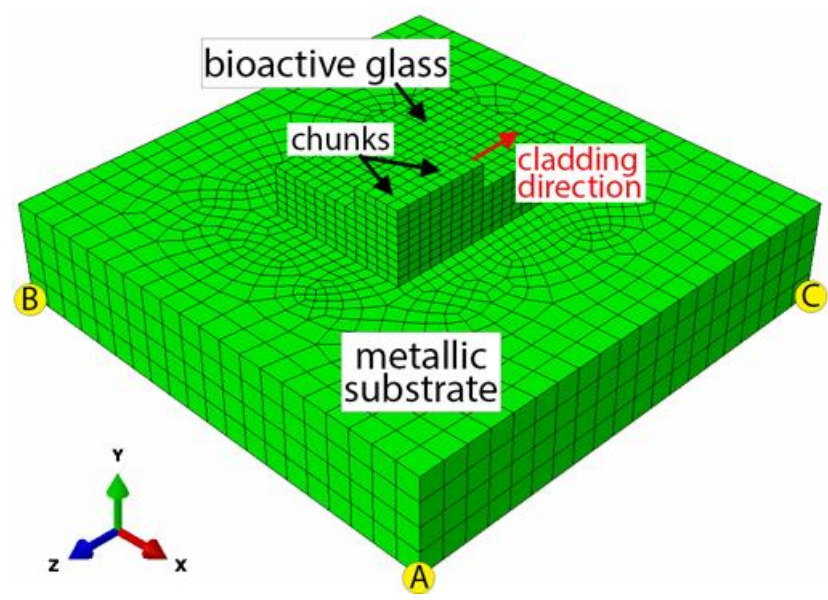

Fig. 2. FE model set-up showing the constrained metallic substrate with cladded layers of bioactive glass (letters A, B and $C$ indicate constrained nodes).

The thermal and mechanical properties of materials used in the modelling are presented in table 1. In case of lack of some material data for ultrafinegrained cpTi Grade 4, the parameters as for conventional cpTi Grade 4 have been assumed or they have been estimated based on available data for similar materials. The properties with indications "after" have been estimated.

Due to lack of temperature dependent stressstrain curves data for the ultrafine-grained cpTi Grade 4 material, its temperature dependent constitutive behaviour has been determined in the following way:

1. the stress-strain data for the ultrafine-grained $\mathrm{cpTi}$ Grade 4 at room temperature are known (figure $3 b$ - curve UFG) and have been used as a basis for the determination of the stress-strain curves at higher temperatures,

2. it has been proved, that the ultrafine-grained structure of cpTi Grade 4 is stable up to about $450^{\circ} \mathrm{C}$ (Zháňal et al., 2016), hence, above that temperature, the stress-strain data for the coarse-grained cpTi Grade 4 at room temperature (figure $3 b-$ curve CG) have been used as a basis for determination of the stress-strain curves at temperatures above $450^{\circ} \mathrm{C}$, 
Table 1. Thermal and mechanical properties of the metallic substrate and bioactive glass used in the numerical analysis.

\begin{tabular}{|c|c|c|}
\hline & ultrafine-grained cpTi, $t\left({ }^{\circ} \mathrm{C}\right)$ & 45S5 bioactive glass \\
\hline Density, $\mathrm{kg} / \mathrm{m}^{3}$ & 4534 (Smirnov, 2019) & 2700 (Grasso et al., 2013) \\
\hline Young's modulus, GPa & $\begin{array}{l}E=-0.0001 t^{2}-0.017 t+104.68 \\
\text { after (Matsumoto et al., 2007; } \\
\text { Rangaswamy et al., 2000) }\end{array}$ & 35 (Thompson \& Hench, 1998) \\
\hline Poisson's coefficient & 0.37 (Boyer et al., 1994) & 0.261 (Srivastava et al., 2012) \\
\hline Yield stress, $\mathrm{MPa}$ & see figure $3 \mathrm{a}$ & 35 (Krzyzanowski et al., 2016) \\
\hline Ultimate tensile strength, $\mathrm{MPa}$ & $\begin{array}{c}U T S=-1.137 t+1152.2 \text { (viable up to } \\
1000^{\circ} \mathrm{C} \text { ), calculated in a similar way as } \\
\text { temperature dependent stress-strain } \\
\text { curves (figure } 3 \mathrm{a} \text { ) }\end{array}$ & 42 (Gerhardt \& Boccaccini, 2010) \\
\hline Linear expansion coefficient, $1 / \mathrm{K}$ & $\begin{array}{l}C T E=1 \times 10^{-12} t^{2}+5 \times 10^{-9} t+9 \times 10^{-6} \\
\text { after (Rangaswamy et al., 2000) }\end{array}$ & $15.1 \times 10^{-6}$ (Bellucci et al., 2011) \\
\hline Heat capacity, J/kgK & $\begin{array}{l}\text { for: } 25^{\circ} \mathrm{C} \leq 950^{\circ} \mathrm{C} \\
c=-0.0001 t^{2}+0.2997 t+532.1 \\
\text { for: } 950^{\circ} \mathrm{C}<\mathrm{t} 950^{\circ} \mathrm{C} \leq 1650^{\circ} \mathrm{C} \\
\mathrm{c}=0.0002 t^{2}-0.3444 t+822.39 \\
\text { after (Yang et al., 2010) }\end{array}$ & 500 after (Zotov, 2002) \\
\hline Latent heat, J/g & 360 (Chassaing et al., 2015) & - \\
\hline Melting temperature, ${ }^{\circ} \mathrm{C}$ & 1668 (Koizumi et al., 2019) & 1183 (Comesaña et al., 2010) \\
\hline Effective thermal conductivity, W/mK & $\begin{array}{l}k=9 \times 10^{-6} t^{2}-0.0054 t+21.173 \\
\text { after ("WWW source no. 1,") }\end{array}$ & 50-90 after (Pilon et al., 2014) \\
\hline Convection coefficient, $\mathrm{W} / \mathrm{m}^{2} \mathrm{~K}$ & 50 (Yang et al., 2010) & 50 (Yang et al., 2010) \\
\hline $\begin{array}{r}\text { Stefan-Boltzmann constant, } \\
\mathrm{W} / \mathrm{m}^{2} \mathrm{~K}^{4}\end{array}$ & $5.67 \times 10^{-8}$ & $5.67 \times 10^{-8}$ \\
\hline Emissivity coefficient & 0.708 (Coppa \& Consorti, 2005) & 0.92 (“WWW source no. $2, ”)$ \\
\hline
\end{tabular}

3. the relationship between the stress-strain curves for various temperatures with the stress-strain curve for room temperature has been established using available data for popular titanium alloy Ti-6Al$4 \mathrm{~V}$. The data have been presented graphically in figure 3c-d. Additionally, data obtained by (Kim et al., 2011) has also been used,

4. the relationship has been determined by defining the dependency ratio coefficients (DRC), where each DRC is a number in the range $(0 \div 1)$ determined by dividing the mean plastic stress at the given temperature by the mean plastic stress at room temperature,

5. DRC have been then used to transform the stressstrain data for the ultrafine-grained and coarsegrained cpTi Grade 4 at the room temperature to stress-strain data at higher temperatures.

During the calculations, equations (1) and (2) have been used to convert the engineering stressstrain curves into their true form. The true strain $\varepsilon_{T}$ has been obtained as given below:
$\varepsilon_{T}=\ln (1+\varepsilon)$

where: $\varepsilon$ - engineering strain.

The true stress $\sigma_{T}$ has been obtained using the following equation:

$\sigma_{T}=\sigma \exp \left(\varepsilon_{T}\right)$

where: $\sigma$ - engineering stress.

The true stresses have been implemented into the Abaqus software as a function of true plastic strain defined as:

$\varepsilon_{T-p l}=\sigma \exp \left(\varepsilon_{T}\right)$

The developed temperature dependent stressstrain curves implemented into numerical model are presented in figure $3 \mathrm{a}$. 

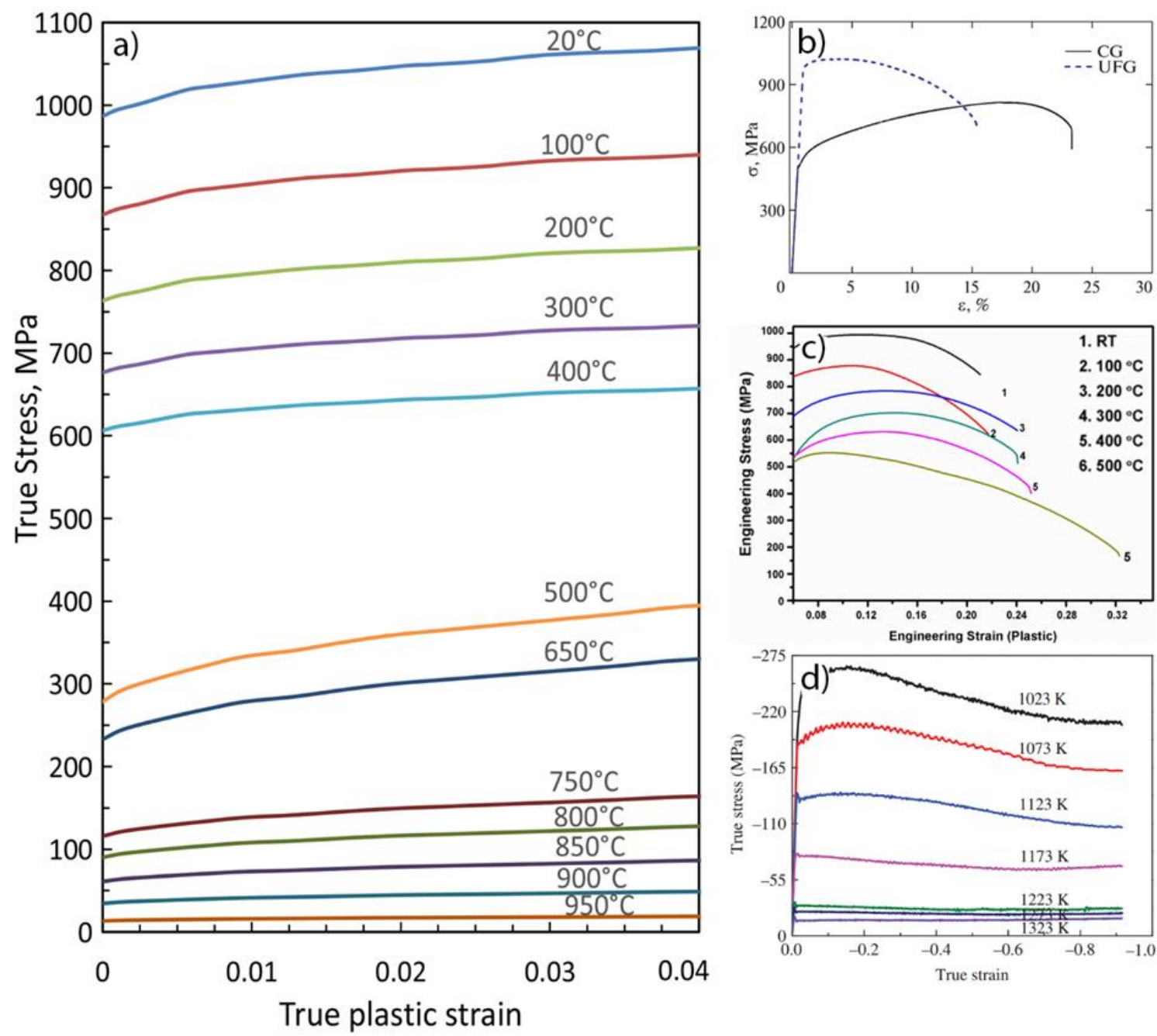

Fig. 3. Stress-strain curves of cpTi Grade 4 and Ti-6Al-4V alloy: a) temperature dependent true stress vs. true plastic strain curves developed for ultrafine-grained cpTi Grade 4 and used in numerical modelling, $b$ ) stress-strain curves of cpTi Grade 4 at room temperature (CG - coarse-grained, UFG - ultrafine-grained) (Smirnov, 2019), c-d) stress-strain curves of Ti-6Al-4V alloy under different temperatures (Kumar et al., 2014; Quan et al., 2015)

\subsection{Laser beam heat source}

The laser radiation has been considered as a volumetric heat source to be absorbed in a volume of a green body as has been described by (Kongsuwan et al., 2015). Laser energy has been defined by a Gaussian distribution in the radial direction and exponential decay in the depth direction using the following equation:

$$
Q(r, z)=Q_{0} \exp \left(\frac{-2 r^{2}}{R_{0}^{2}}\right) \exp (-\alpha z)
$$

where: $Q(r, z)$ - heat flux at point $(r, z), r$-radial coordinate, $z$ - vertical coordinate, $Q_{0}$ - peak flux, $R_{0}-$ radius of the laser beam on the top surface, $\alpha-$ absorption coefficient of the green body.

The peak flux $Q_{0}$ is defined as follows:

$$
Q_{0}=\frac{Q_{L}}{\pi R_{0}^{2} d}
$$

where: $Q_{L}$ - laser power, $d$ - heat penetration depth.

The heat source defined by equation 4 has been implemented into the model using DFLUX subroutine. The laser power, the radius of the laser spot and the scanning speed have been changed as follows: 76 $-140 \mathrm{~W}, 0.6 \mathrm{~mm}$ and $4-6 \mathrm{~mm} / \mathrm{s}$, respectively. The initial temperatures of the metallic substrate for the non-preheated and preheated cases have been correspondingly assumed as 20 and $300^{\circ} \mathrm{C}$. The preheating of the base material allows for decreasing of the laser power and lowers the cooling speed between the consecutive temperature peaks contributing which in consequence results in achievement of lower cracking susceptibility (Krzyzanowski et al., 2016). The initial temperature of the elements representing the cladded material at the moment of their activation has been 
assumed to $1100^{\circ} \mathrm{C}$ as the bioactive powder is heated up by the laser beam also before it gets on the substrate.

\section{RESULTS AND DISCUSSION}

Temperatures, stress and strain distributions, varying over time, have been calculated for different laser cladding process parameters.

\subsection{Temperature distribution}

Figure 4 shows the temperature distribution within the cladded bioactive glass and ultrafinegrained cpTi Grade 4 substrate during the laser cladding process for different scanning speeds: 4,5 and 6 $\mathrm{mm} / \mathrm{s}$. The laser power has been assumed to 140,115 and $95 \mathrm{~W}$ during cladding of the first, second and third layer, respectively. For the lowest scanning speed only two layers have been cladded (figure 4a), as the relatively low movement speed of the laser beam caused a significant increase in temperature. A conclusion can be drawn, that the lower laser power can be used to obtain similar temperatures at reduced scanning speed.
The temperature distribution for preheated to $300^{\circ} \mathrm{C}$ metallic substrate in comparison with not preheated substrate for $5 \mathrm{~mm} / \mathrm{s}$ scanning speed has been shown in figure 5 . In order to obtain similar temperature values in laser beam spot, different laser powers have been used. For the not preheated case the laser power has been the same (i.e. 140, 115 and $95 \mathrm{~W}$ depending on the layer cladded), while for the preheated case the laser power has been decreased by $20 \%$ (to 112, 92 and $76 \mathrm{~W}$, respectively).

Despite the reduction in laser power, the temperatures obtained in the center of the laser beam spot are comparable. However, the area of such high temperature values is larger for the preheated case, which can result from the slower heat dissipation from the center of the laser spot due to higher temperatures in its neighbourhood than in the case of the not preheated substrate. During cladding of the second layer, the temperature reaches about $400^{\circ} \mathrm{C}$ for the not preheated substrate and about $600^{\circ} \mathrm{C}$ for the preheated one.
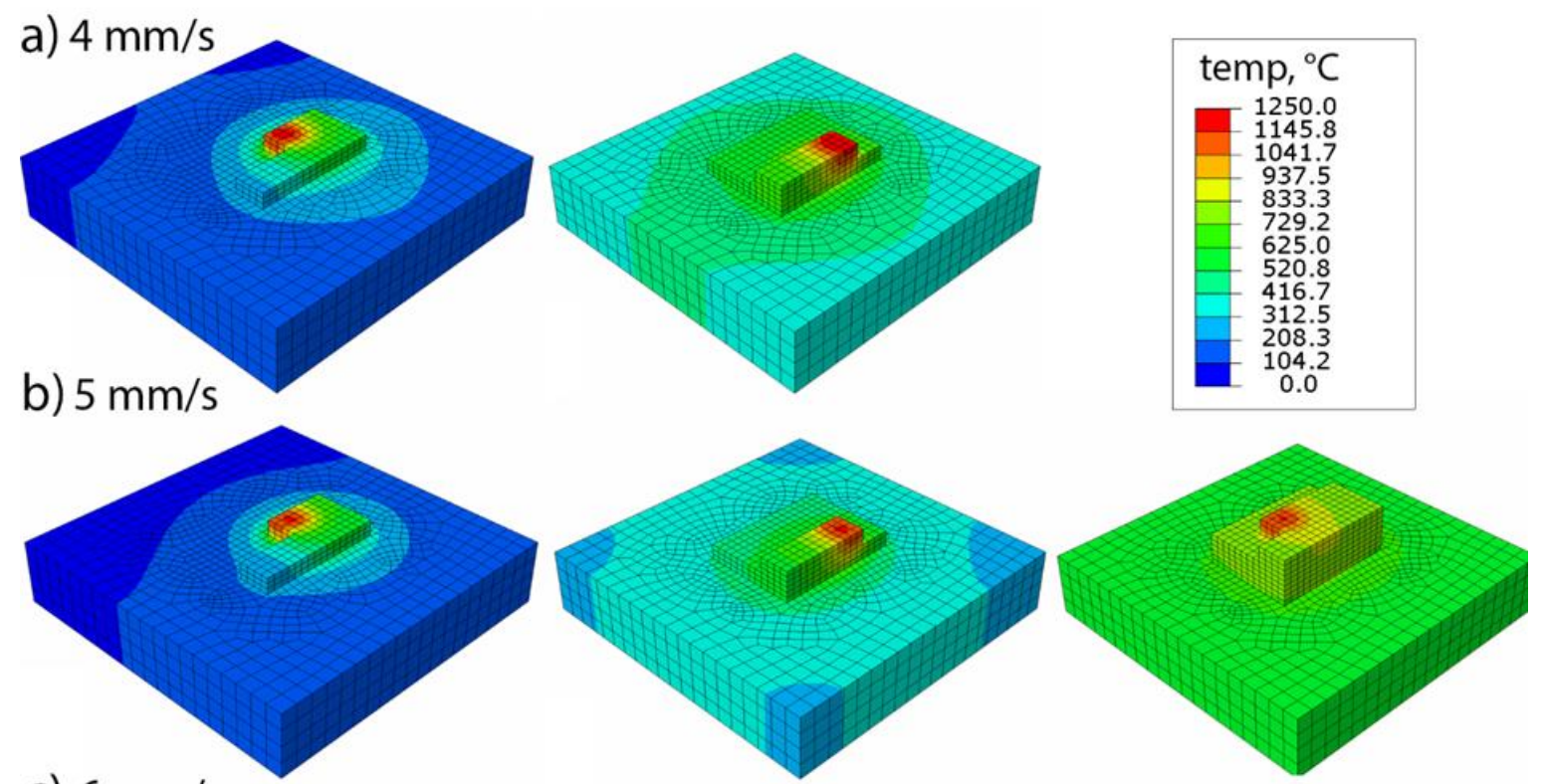

c) $6 \mathrm{~mm} / \mathrm{s}$
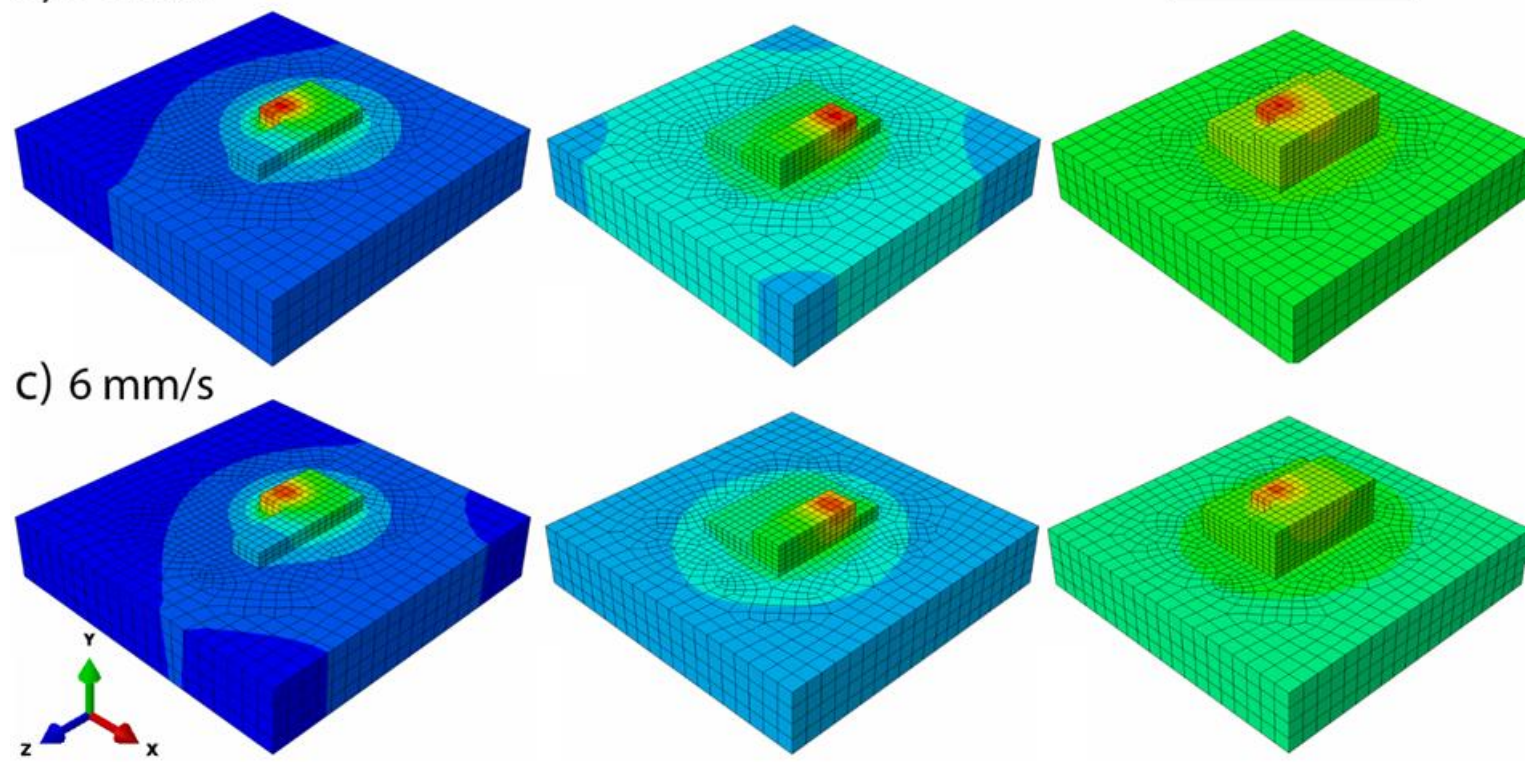

Fig. 4. Temperature distribution within the cladded material and the substrate predicted for different time moments of the laser cladding process for various scanning speeds, i.e. $4(a), 5(b)$ and $6 \mathrm{~mm} / \mathrm{s}(c)$. 
a) not preheated: 140,115 and $95 \mathrm{~W}$

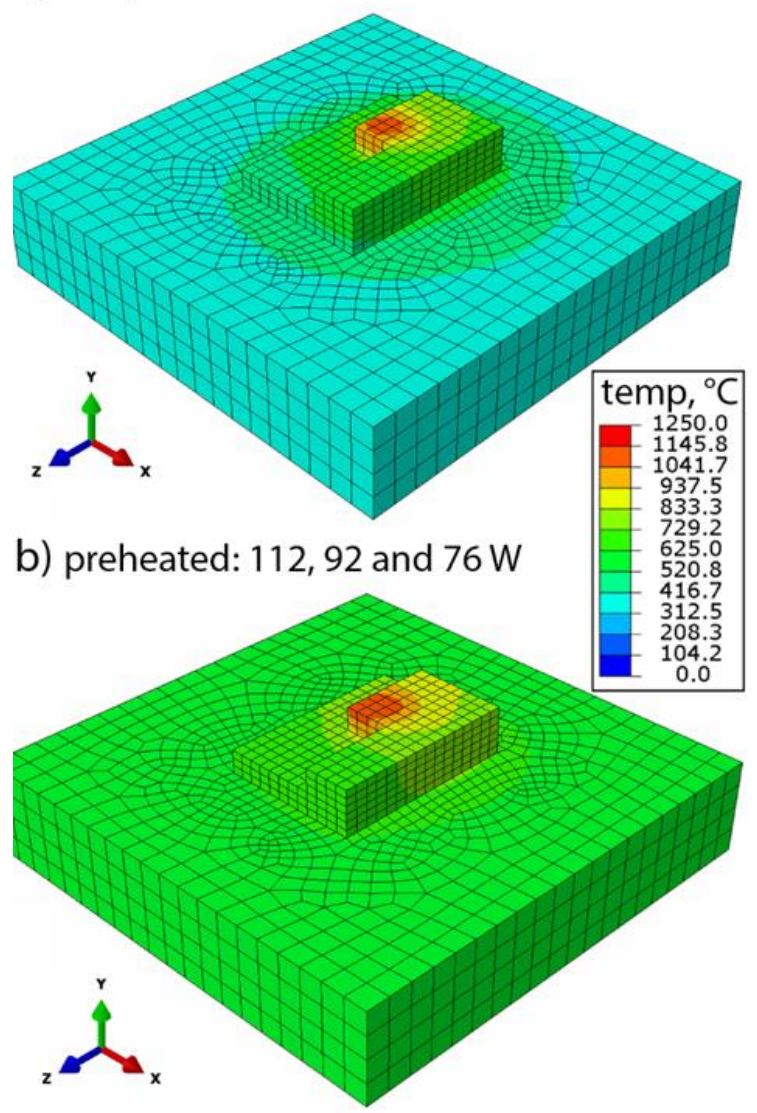

Fig. 5. Temperature distribution within the cladded material and the substrate predicted for not preheated (a) and preheated $(b)$ substrates using different laser powers for the subsequent layers.

It can be seen in figure 6, that the moment the laser beam passes through the node (or next to it - in the case of node B and C), the highest temperature has been achieved at node $\mathrm{A}$, lower at node $\mathrm{B}$ and the lowest at node $\mathrm{C}$ for both not preheated and preheated cases. During the cladding of the second and third layer, the temperatures have been similar for all chosen nodes. It can be concluded that the temperatures in the areas over which the laser beam passes and in the vicinity of them are similar for both not preheated and preheated substrate. In other areas, the calculated temperatures are about $100^{\circ} \mathrm{C}$ higher for the preheated substrate.

\subsection{Stress distribution}

The stress distribution in the bioactive material and ultrafine-grained cpTi after the laser cladding process is shown in figure $7 \mathrm{a}$. In the first case, the metallic substrate has not been preheated, whereas preheating to $300^{\circ} \mathrm{C}$ has been applied in the second case. It can be seen that the preheating operation allowed for reduction of stresses both in the substrate and in the bioactive material. There is a risk that cracking in the cladded bioactive glass can occur in both cases as the stresses reach UTS limit in some regions.
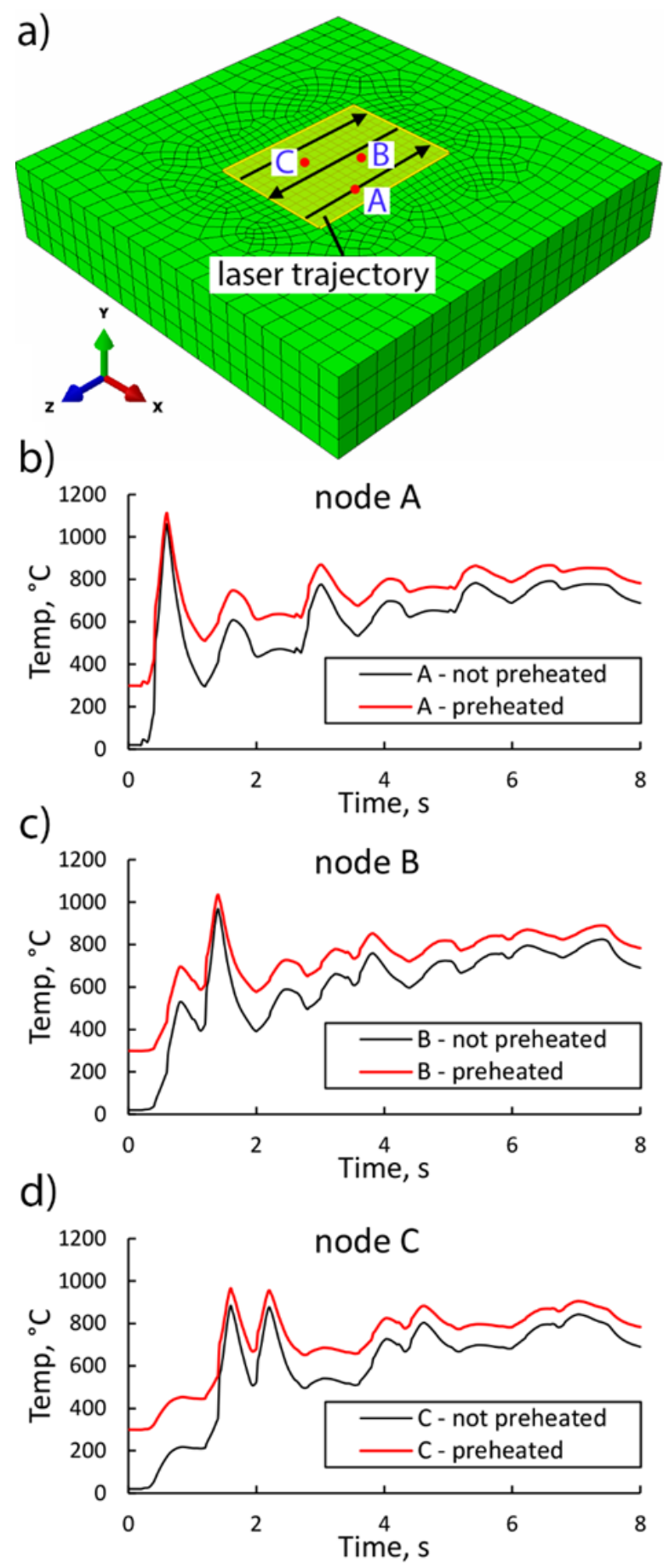

Fig. 6. a) Surface area of the substrate affected by the laser beam with marked trajectory and nodes $A, B$ and $C, b-d)$ the variation of temperature with time at nodes $A, B$ and $C$ on the substrate surface predicted during laser cladding of bioactive glass for different initial temperatures of the substrate and using different laser powers for the subsequent layers, namely: 140, 115 and 95 $W$ for the not preheated case and 112, 92 and $76 \mathrm{~W}$ for the preheated one. 
In order to analyse the stress distribution in ultrafine-grained cpTi substrate during the laser cladding process, the elements representing bioactive glass have been hidden as presented in figure $7 \mathrm{~b}$, which shows the effective stress distribution during the cladding of the first bioactive layer. The laser beam transmitted through the elements of the first layer has been affecting the surface areas of the substrate (marked as 'laser beam spot' in figure 7b). It is clearly visible, that the effective stress developed in these areas of the highest temperature is lower than the stress developed closer to the periphery zone, where the temperature is lower. It results from the thermal expansion of the material and can affect neighbouring areas during cladding of multi tracks.

The transient effective stress developed on the substrate surface at the chosen nodes A, B and C (figure 6a) during the bioactive glass laser cladding process have been presented in figure 8. The mark "UTS" in the legend of the charts denotes the temperature dependent ultimate tensile strength, which has been calculated using equation from table 1 . As the equation is viable up to $1000^{\circ} \mathrm{C}$, the fixed value of 20 $\mathrm{MPa}$ has been assumed above that temperature.
It can be seen, that for node A, located directly on the path of the moving laser beam, the equivalent stress exceeds the UTS limit when the laser beam passes through it for the not preheated metallic substrate (figure 8a). For the preheated substrate, the transient stresses for node $\mathrm{A}$ are significantly smaller, however still above the UTS limit. For node B, which is located $1 \mathrm{~mm}$ away from the laser path, the stresses are lower than for node A, however they exceed the UTS limit when the laser beam passes next to it in the not preheated case (figure $8 b$ ). For the preheated case, the stresses are also lower, slightly above the UTS limit. For node $\mathrm{C}$, which is located $2 \mathrm{~mm}$ away from two paths, the stresses exceed slightly UTS limit when the laser beam passes next to it through the first path. During passing through the second path, the UTS limit is not reached for the not preheated substrate (figure $8 \mathrm{c}$ ). For the preheated case, the stresses are a little lower but their relation with the UTS limit is similar as for the not preheated substrate. It can be concluded, that preheating of the substrate allows for stress reduction and therefore for decrease of the cracking susceptibility of the ultrafine-grained cpTi metallic substrates.

a)
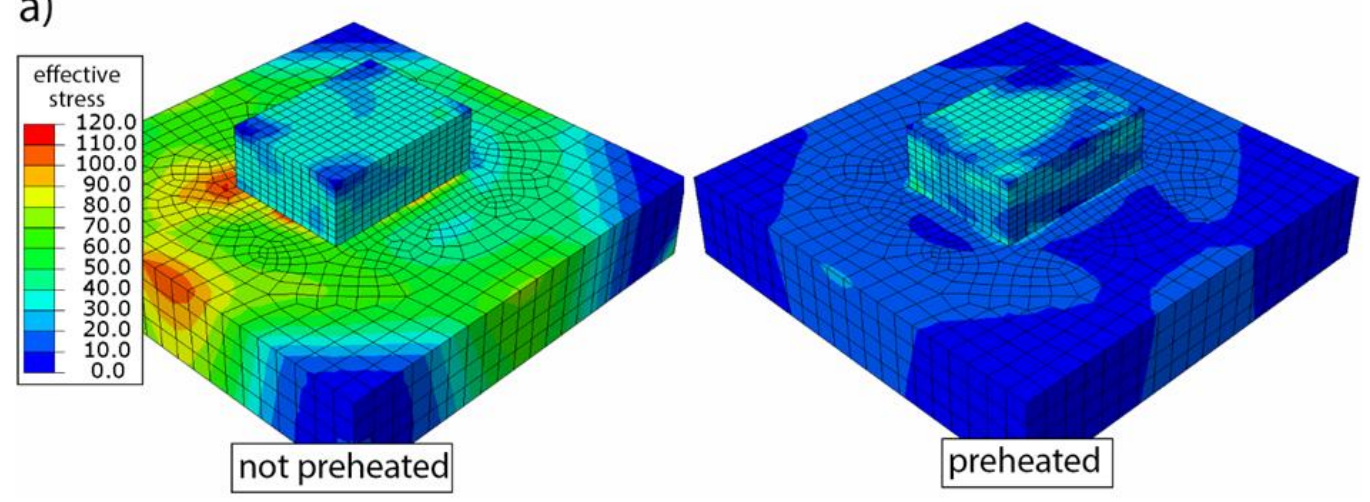

b)
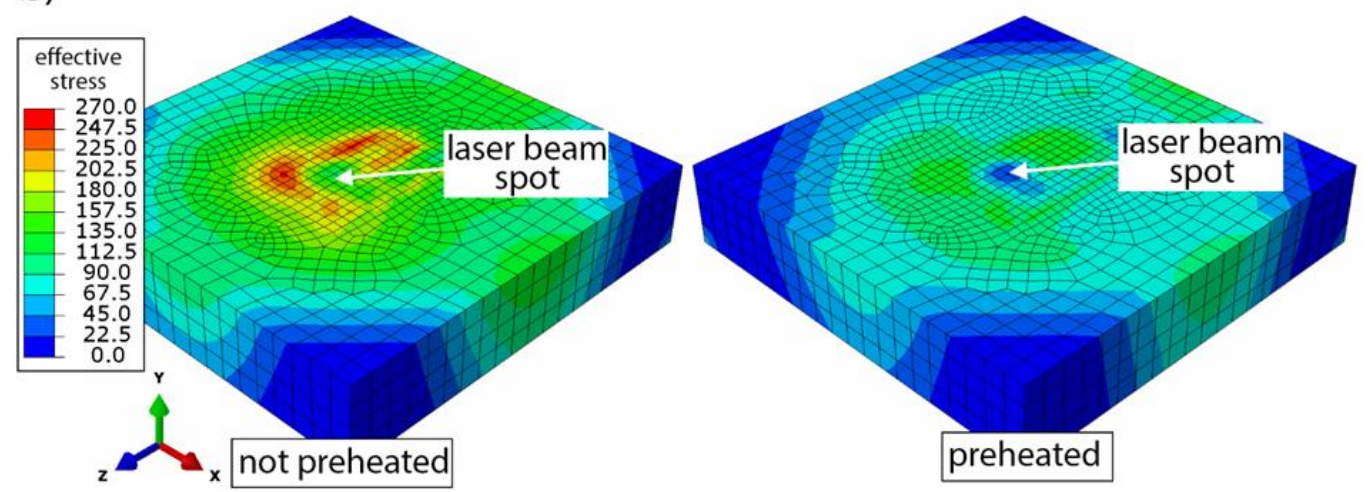

Fig. 7. Effective stress distribution within the cladded material and the substrate after the laser cladding process (a) and within the substrate during cladding of the first layer $(b)$. 

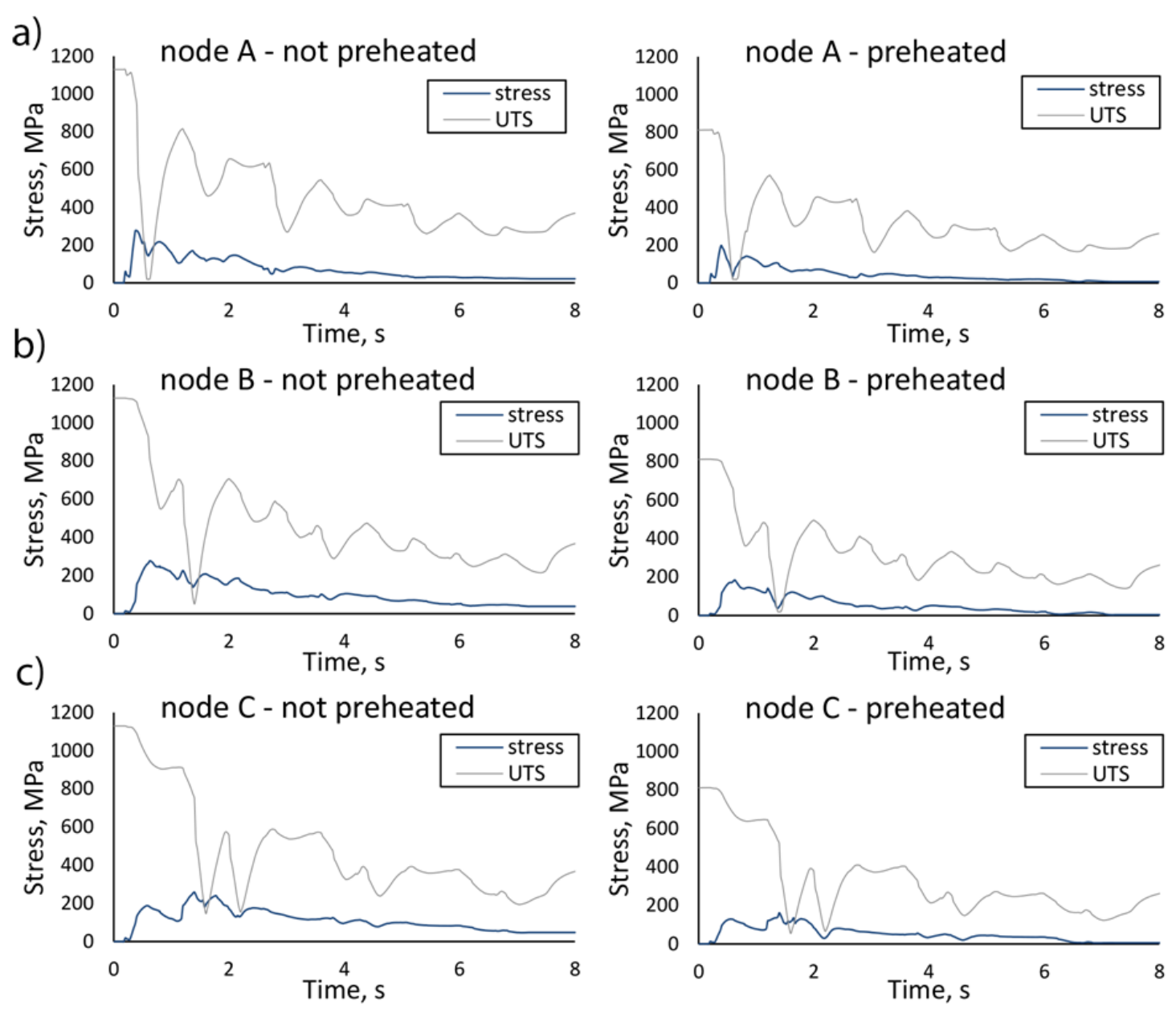

Fig. 8. Transient effective stress predicted during laser cladding from nodes $A(a), B(b)$ and $C(c)$ localized on the substrate surface for different initial temperatures of the substrate and different laser powers for the subsequent layers: 140, 115 and $95 \mathrm{~W}$ for the not preheated case and 112, 92 and $76 \mathrm{~W}$ for the preheated one.

It has been shown experimentally (Krzyzanowski et al., 2016), that laser cladding of a single layer bioactive glass (nominal composition: $56.5 \% \mathrm{SiO}$, $11.0 \% \mathrm{Na} 2 \mathrm{O}, 3.0 \% \mathrm{~K} 2 \mathrm{O}, 15.0 \% \mathrm{CaO}, 8.5 \% \mathrm{MgO}$, and $6.0 \% \mathrm{P} 2 \mathrm{O} 5)$ on the coarse-grained Ti-6Al-4V substrate caused cracking in the not preheated base plate directly on the path of the moving laser beam (figure 9), which is in agreement with the results of the numerical analysis (figure 8a). Parameters of the laser cladding process have been similar to applied in the numerical modelling, i.e. $5 \mathrm{~mm} / \mathrm{s}$ scanning speed, $0.6 \mathrm{~mm}$ radius of the laser spot and $120 \mathrm{~W}$ laser power. Although the applied bioactive glass and metallic substrate are somewhat different, the yield stress and UTS of Ti-6Al-4V used in the experimental studies has only been slightly lower than for the ultrafine-grained cpTi Grade 4 applied in the numerical modelling.

Figure 10 shows the transient temperature and equivalent stress predicted at node $\mathrm{A}$ during the laser cladding process for the same laser power and differ- ent velocity of the laser beam: 5 and $6 \mathrm{~mm} / \mathrm{s}$. The obtained temperatures are close to each other for both cases being slightly lower for higher laser speed (figure 10a). The calculated transient stresses are also similar to each other (figure 10b).

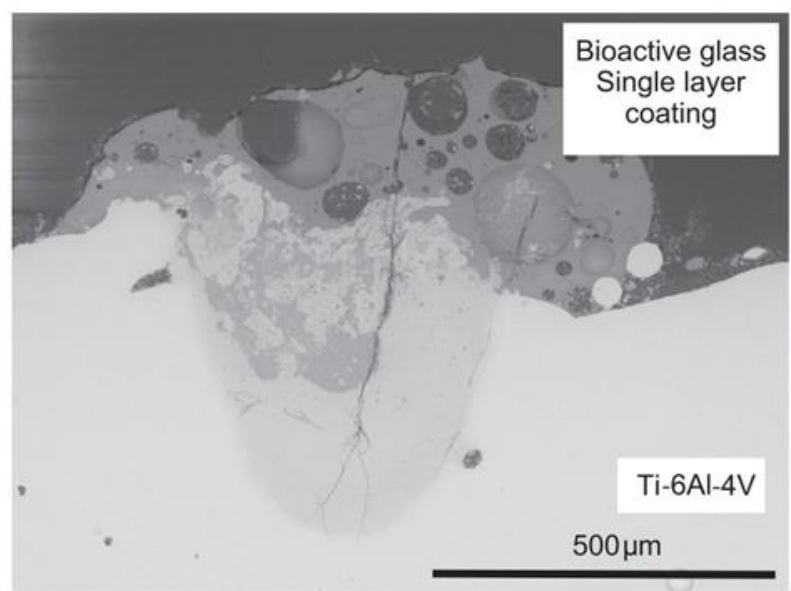

Fig. 9. SEM image of the cross-section of the single bioactive glass coating on the not preheated Ti-6Al-4V substrate showing a crack formed in the metallic substrate located in directly on the path of the moving laser beam (Krzyzanowski et al., 2016). 


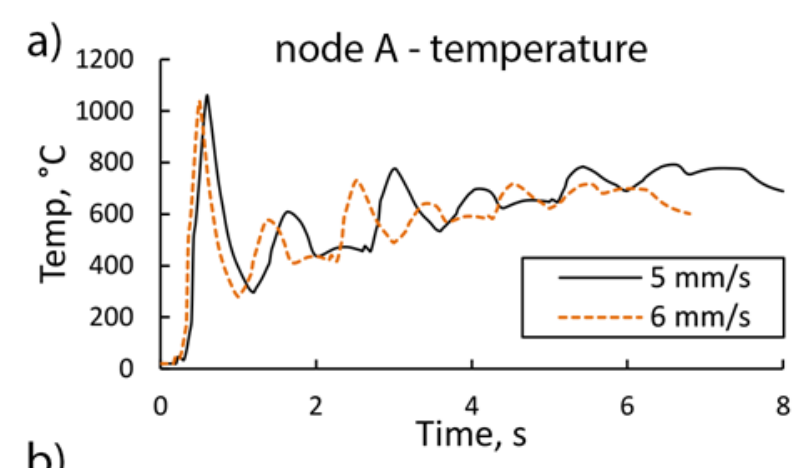

b)

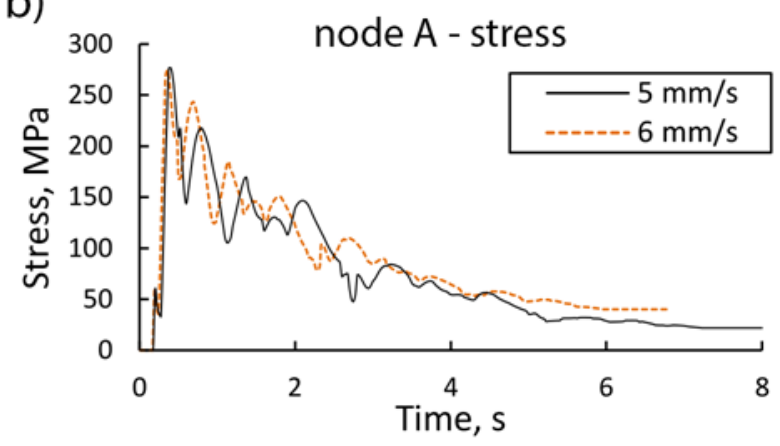

Fig. 10. The transient temperature (a) and effective stress (b) predicted during laser cladding at node A localized on the substrate surface using different scanning speeds: 5 and $6 \mathrm{~mm} / \mathrm{s}$.

\section{CONCLUSIONS}

A 3D numerical model of the laser cladding process has been developed considering multiple bioactive glass coatings on the ultrafine-grained cpTi substrate. The model is able to predict the transient stress-strain and temperature distributions. The simulations of laser cladding of three layers of 45S5 bioactive glass have been performed and the following conclusions have been drawn:

1. Lower laser power can be used to obtain desired temperatures at reduced scanning speed.

2. Preheating of the metallic substrate allows for laser power reduction.

3. In addition, the preheating operation allowed for reduction of stresses in both the substrate and bioactive glass.

4. The predicted stresses in the metallic substrate exceeded the UTS limit in the areas under the laser beam passes for the not preheated and also for the preheated case

The developed numerical model is able to support the optimal design of advanced multi-layered structural materials obtained using the laser cladding technique. The next step of the work is further validation of the developed model through additional experimental studies and extension of the model in order to predict the crystallization and porosity distributions.

\section{ACKNOWLEDGMENTS}

The support from the National Science Centre, Poland (grant no. DEC-2016/21/N/ST8/00091) is greatly appreciated. This research was supported in part by PLGrid Infrastructure.

\section{REFERENCES}

Baino, F., Verné, E., 2017, Glass-based coatings on biomedical implants: a state-of-the-art review, Biomed. Glas., 3(1), 117.

Bellucci, D., Cannillo, V., Sola, A., 2011, Coefficient of thermal expansion of bioactive glasses: Available literature data and analytical equation estimates, Ceram. Int., 37(8), 29632972.

Bergmann, C., Stumpf, A., 2013, Dental ceramics, dental ceramics: microstructure, properties and degradation, Springer, Berlin Heidelberg.

Boyer, R., Collings, E.W., Welsch, G., 1994, Materials Properties Handbook Titanium Alloys, ASM International. Retrieved from https://www.asminternational.org/materialsresources/results/-/journal_content/56/10192/06005G/ PUBLICATION

Cao, W., Hench, L. L., 1996, Bioactive materials, Ceram. Int., 22(6), 493-507.

Chassaing, G., Pougis, A., Philippon, S., Lipinski, P., Meriaux, J., 2015, Experimental and numerical study of frictional heating during rapid interactions of a Ti6Al4V tribopair, Wear, 342-343, 322-333.

Comesaña, R., Quintero, F., Lusquiños, F., Pascual, M.J., Boutinguiza, M., Durán, A., Pou, J., 2010, Laser cladding of bioactive glass coatings, Acta Biomater., 6(3), 953-961.

Coppa, P., Consorti, A., 2005, Normal emissivity of samples surrounded by surfaces at diverse temperatures, Measurement, 38(2), 124-131.

Del Val, J., López-Cancelos, R., Riveiro, A., Badaoui, A., Lusquiños, F., Quintero, F., Pou, J., 2016, On the fabrication of bioactive glass implants for bone regeneration by laser assisted rapid prototyping based on laser cladding, Ceram. Int., 42(1), 2021-2035.

Dorozhkin, S.V., 2016, Multiphasic calcium orthophosphate (CaPO4) bioceramics and their biomedical applications, $\mathrm{Ce}$ ram. Int., 42(6), 6529-6554.

Elias, C.N., Meyers, M.A., Valiev, R.Z., Monteiro, S.N., 2013, Ultrafine grained titanium for biomedical applications: An overview of performance, J. Mater. Res. Technol., 2(4), 340-350

Gerhardt, L.-C., Boccaccini, A.R., 2010, Bioactive glass and glass-ceramic scaffolds for bone tissue, Engineering. Mater., 3(7), 3867-3910.

Grasso, S., Chinnam, R.K., Porwal, H., Boccaccini, A.R., Reece, M.J., 2013, Low temperature spark plasma sintering of 45S5 Bioglass ${ }^{\circledR}$, J. Non. Cryst. Solids, 362(1), 25-29.

Hench, L. L., 1991, Bioceramics: From Concept to Clinic, J. Am. Ceram. Soc., 74(7), 1487-1510.

Hench, L. L., 1998, Biomaterials: A forecast for the future, Biomaterials, 19(16), 1419-1423. 
Hench, L.L., Paschall, H.A., 1973, Direct chemical bond of bioactive glass-ceramic materials to bone and muscle, J. Biomed. Mater. Res., 7(3), 25-42.

Hench, L.L., Wilson, J., 1993, An Introduction to Bioceramics, World Scientific.

Kar, S., 2016, An overview of recent advances in application of some inorganic materials-biological and technological perspectives, J. Biotechnol. Biomater., 6(3), 1-7.

Kim, J.H., Semiatin, S.L., Lee, Y.H., Lee, C.S., 2011, A self-consistent approach for modeling the flow behavior of the alpha and beta phases in Ti-6Al-4V, Metall. Mater. Trans. A, 42(7), 1805-1814.

Koizumi, H., Takeuchi, Y., Imai, H., Kawai, T., Yoneyama, T., 2019, Application of titanium and titanium alloys to fixed dental prostheses, J. Prosthodont. Res., 66(3), 266-270.

Kongsuwan, P., Brandal, G., Lawrence Yao, Y., 2015, Laser induced porosity and crystallinity modification of a bioactive glass coating on titanium substrates, J. Manuf. Sci. Eng., 137(3), 031004

Krzyzanowski, M., Bajda, S., Liu, Y., Triantaphyllou, A., Mark Rainforth, W., Glendenning, M., 2016, 3D analysis of thermal and stress evolution during laser cladding of bioactive glass coatings, J. Mech. Behav. Biomed. Mater., 59, 404417.

Kumar, S., Chattopadhyay, K., Singh, V., 2014, Tensile behavior of Ti-6Al-4V alloy at elevated temperatures, In International Conference Multifunctional Materials, Structures and Applications, Allahabad, 115-118.

Liu, X., Chu, P.K., Ding, C., 2004, Surface modification of titanium, titanium alloys, and related materials for biomedical applications, Mater. Sci. Eng. R Reports, 47(3-4), 49-121.

Madeo, A., 2015, Remodeling of bone reconstructed with bio-resorbable materials, In Generalized Continuum Mechanics and Engineering Applications, ISTE Press Ltd., London, 83108.

Matsumoto, H., Watanabe, S., Hanada, S., 2007, $\alpha^{\prime}$ Martensite TiV-Sn alloys with low Young's modulus and high strength, Mater. Sci. Eng. A, 448(1-2), 39-48.

Miguez-Pacheco, V., Hench, L.L., Boccaccini, A.R., 2015, Bioactive glasses beyond bone and teeth: Emerging applications in contact with soft tissues, Acta Biomater., 13, 1-15.

Pilon, L., Janos, F., Kitamura, R., 2014, Effective thermal conductivity of soda-lime silicate glassmelts with different iron contents between $1100^{\circ} \mathrm{C}$ and $1500^{\circ} \mathrm{C}, \mathrm{J}$. Am. Ceram. Soc., 97(2), 442-450

Pou, J., Lusquiños, F., Comesaña, R., Boutinguiza, M., 2010, Production of biomaterial coatings by laser-assisted processes, In Advances in Laser Materials Processing, Woodhead Publishing Limited, Boca Raton, 394-425.

Quan, G.-Z., Wen, H.-R., Pu, S.-A., Zou, Z.-Y., Wu, D.-S., 2015 , Identification of stable processing parameters in $\mathrm{Ti}-6 \mathrm{Al}-4 \mathrm{~V}$ alloy from a wide temperature range across $\beta$ transus and a large strain rate range, High Temp. Mater. Process., 34(7), 715-729.

Ramaswamy, Y., Wu, C., Zreiqat, H., 2009, Orthopedic coating materials: Considerations and applications, Expert Rev. Med. Devices, 6(4), 423-430.

Rangaswamy, P., Choo, H., Prime, M.B., Bourke, M.A.M., Larsen, J.M., 2000, High Temperature stress assessment in SCS-6/Ti-6Al-4V composite using neutron diffraction and finite element modeling, In Int. Conf. on Processing \& Manufacturing of Advanced Material, Las Vegas.
Schlegel, U.J., Bishop, N.E., Püschel, K., Morlock, M.M., Nagel, K., 2014, Comparison of different cement application techniques for tibial component fixation, in: TKA, Int. Orthop., 47-54.

Shi, J.Z., Chen, C.Z., Zhang, S., Wu, Y., 2007, Application of surface modification in biomedical materials research, Surf. Rev. Lett., 14(03), 361-369.

Smirnov, I.V., 2019, Strength characteristics and fracture of ultrafine-grained titanium grade 4 processed by equal channel angular pressing - conform, Tech. Phys., 64(4), 497-505.

Sola, A., Bellucci, D., Cannillo, V., Cattini, A., 2011, Bioactive glass coatings: a review, Surf. Eng., 27(8), 560-572.

Srivastava, A.K., Pyare, R., Singh, S.P., 2012, Elastic properties of substituted 45S5 bioactive glasses and glass - ceramic, Int J Sci. Eng. Res., 3(2), 290-302. Retrieved from http://www.ijser.org

Stolyarov, V.V., Zhu, Y.T., Alexandrov, I.V., Lowe, T.C., Valiev, R.Z., 2003, Grain refinement and properties of pure Ti processed by warm ECAP and cold rolling, Mater. Sci. Eng. A, 343(1-2), 43-50.

Thompson, I.D., Hench, L.L., 1998, Mechanical properties of bioactive glasses, glass-ceramics and composites, Proc. Inst. Mech. Eng. Part H J. Eng. Med., 212(2), 127-136.

Vallet-Regí, M., 2010, Evolution of bioceramics within the field of biomaterials, Comptes Rendus Chim., 13(1-2), 174-185.

Verné, E., 2012, Bioactive glass and glass-ceramic coatings, In R. Jones \& A. G. Clare (Eds.), Bio-Glasses, John Wiley \& Sons, Ltd., Chichester, 107-119.

WWW source no. 1, (n.d.). Retrieved June 14, 2019, from https://www.efunda.com/materials/elements/TC_Table.cfm?Element_ID=Ti

WWW source no. 2, (n.d.). Retrieved June 25, 2019, from https://www.engineeringtoolbox.com/emissivity-coefficients-d_447.html

Yang, J., Sun, S., Brandt, M., Yan, W., 2010, Experimental investigation and $3 \mathrm{D}$ finite element prediction of the heat affected zone during laser assisted machining of Ti6Al4V alloy, J. Mater. Process. Technol., 210(15), 2215-2222.

Zháňal, P., Václavová, K., Hadzima, B., Harcuba, P., Stráský, J., Janeček, M., Hajizadeh, K., 2016, Thermal stability of ultrafine-grained commercial purity $\mathrm{Ti}$ and $\mathrm{Ti}-6 \mathrm{Al}-7 \mathrm{Nb}$ alloy investigated by electrical resistance, microhardness and scanning electron microscopy, Mater. Sci. Eng. A, 651, 886892.

Zotov, N., 2002, Heat capacity of sodium silicate glasses: comparison of experiments with computer simulations, J. Phys. Condens. Matter, 14(45), 11655-11669.

\section{ANALIZA NUMERYCZNA PROCESU NAPAWANIA LASEROWEGO POWLOK SZKLA BIOAKTYWNEGO NA ULTRADROBNOZIARNISTE PODLOŻA TYTANOWE}

\section{Streszczenie}

Stopy tytanu są obecnie powszechnie stosowane do produkcji implantów medycznych ze względu na wyjątkowe własności mechaniczne i biokompatybilność. Jednakże obecność takich pierwiastków jak aluminium i wanad może być szkodliwa dla zdrowia ludzkiego. Jednym z możliwych rozwiązań tego problemu 
może być zastąpienie stopów tytanu ultradrobnoziarnistym komercyjnie czystym tytanem (cpTi), którego granica plastyczności i wytrzymałość na rozciąganie cpTi może przekraczać nawet $1000 \mathrm{MPa}$. Jedną z najbardziej obiecujących metod produkcji implantów medycznych jest napawanie laserowe, w którym powłoki szkła bioaktywnego są nakładane na podłoża metaliczne. Celem pracy było opracowanie modelu numerycznego $3 \mathrm{D} \mathrm{w} / \mathrm{w}$ procesu wytwarzania przyrostowego. Otrzymany model jest w stanie przewidywać rozkłady naprężeń, odkształceń i temperatur występujących w trakcie procesu. Opracowano model sekwencyjny napawania laserowego wykorzystując metodę elementów skończonych (MES) i technikę dezaktywacji i aktywacji elementów skończonych, co pozwoliło obliczyć przejściowe pola temperatury, które wykorzystano następnie do analizy naprężeń. Skoncentrowane objętościowe źródło ciepła wiązki laserowej przemieszczajacej się wzdłuż powierzchni metalu było opisane za pomocą rozkładu Gaussa. Opracowany model numeryczny może wspomóc projektowanie i wytwarzanie zaawansowanych wielowarstwowych materiałów z wykorzystaniem techniki napawania laserowego

Received: October 1, 2019 Received in a revised form: November 12, 2019. Accepted: December 2, 2019. 